\title{
Protein intake and nutritional programming: metabolic consequences
}

\author{
Elvira Verduci*, Benedetta Mariani, Carlotta Lassandro, Alice ReDionigi \\ From 70th Congress of the Italian Society of Pediatrics, Joint National Meeting SIP, SICuPP, SITIP \\ Palermo, Italy. 11-14 June 2014
}

According to recent epidemiological evidence, early protein intakes that exceeds metabolic requirements $(>15 \%$ of energy) may increase weight gain during infancy and the risk of developing obesity in childhood: the so-called "early protein hypothesis" [1]. A high protein intake, indeed, especially milk's protein $[2,3]$, may enhance the secretion of insulin and insulin-like growth factor-I (IGFI), associated with increased weight gain during the first 2 years of life, increase of adipocyte differentiation and adipogenic activity [4]. In a large number of studies increased weight gain in infancy and early adiposity rebound have been associated with the development of later obesity [4]. The presence of a positive strong association between early protein intake and increased weight gain in early childhood has been recently demonstrated in the European Childhood Obesity Project (CHOP): a multicenter, double-blind intervention trial involving both formula fed infants, randomly assigned to receive, during the first year of life, infant and follow-on formulas with different protein content (high or low), and breastfed infants as control group. This trial showed that both weight-for-length and BMI z-scores were significantly higher in the high protein (HP) compared with the low protein (LP) group at 12 and 24 months [5]. Moreover the body composition analysis at 6 months of life showed that weight gain velocity from baseline to 6 months was significantly associated with fat mass, proving that higher early protein intakes may influence adiposity [6]. Concerning metabolic data, HP group compared with LP group showed higher plasma concentrations of branched chain aminoacids, IGF-I and insulin at 6 months. Moreover, IGF-I concentrations have been associated with weight gain in the first 6 months of life [7]. Additionally IGF-I could partly mediate protein-induced kidney growth in healthy children [8]. This phenomenon was observed in the HP group: children at 6 months of life

Department of Pediatrics, San Paolo Hospital, Department of Health Sciences, University of Milan, Milan, Italy
1. Riva E, Verduci E, Giovannini M, Agostoni C: Early protein intakes and adiposity: reloaded or downloaded. Acta Paediatr 2004, 93:725-726.

2. Hoppe C, Mølgaard C, Vaag A, Barkholt V, Michaelsen KF: High intakes of milk, but not meat, increase s-insulin and insulin resistance in 8-year-old boys. Eur J Clin Nutr 2005, 59:393-398.

3. Hoppe C, Mølgaard C, Juul A, Michaelsen KF: High intakes of skimmed milk, but not meat, increase serum IGF-I and IGFBP-3 in eight-year-old boys. Eur J Clin Nutr 2004, 58:1211-1216.

Koletzko B, von Kries R, Closa R, Escribano J, Scaglioni S, Giovannini M, Beyer J, Demmelmair H, Anton B, Gruszfeld D, Dobrzanska A, Sengier A, Langhendries JP, Rolland Cachera MF, Grote V: Can infant feeding choices modulate later obesity risk? Am J Clin Nutr 2009, 89:1502S-1508S.

5. Koletzko B, von Kries R, Closa R, Escribano J, Scaglioni S, Giovannini M, Beyer J, Demmelmair H, Gruszfeld D, Dobrzanska A, Sengier A, Langhendries JP, Rolland Cachera MF, Grote V, European Childhood Obesity Trial Study Group: Lower protein in infant formula is associated with lower weight up to age 2 y: a randomized clinical trial. Am J Clin Nutr 2009, 89:1836-1845.

6. Escribano J, Luque V, Ferre N, Mendez-Riera G, Koletzko B, Grote V, Demmelmair H, Bluck L, Wright A, Closa-Monasterolo R, European Childhood Obesity Trial Study Group: Effect of protein intake and weight gain velocity on body fat mass at 6 months of age: the EU Childhood Obesity Programme. Int J Obes 2012, 36:548-53.

Socha P, Grote V, Gruszfeld D, Janas R, Demmelmair H, ClosaMonasterolo R, Subías JE, Scaglioni S, Verduci E, Dain E, Langhendries JP, protein intake, the metabolic-endocrine response, and growth in infancy: data from a randomized clinical trial. Am J Clin Nutr 2011, 94(Suppl):1776S-1784S. 
8. Luque V, Escribano J, Grote V, Ferre N, Koletzko B, Gruszfeld D, Socha P, Langhendries JP, Goyens P, Closa-Monasterolo R, European Childhood Obesity Project: Does insulin-like growth factor-1 mediate proteininduced kidney growth in infants? A secondary analysis from a randomized controlled trial. Pediatr Res 2013, 74:223-229.

9. Escribano J, Luque V, Ferre N, Zaragoza-Jordana M, Grote V, Koletzko B, Gruszfeld D, Socha P, Dain E, Van Hees JN, Verduci E, Closa-Monasterolo R: Increased protein intake augments kidney volume and function in healthy infants. Kidney Int 2011, 79:783-90.

10. Weber M, Grote V, Closa-Monasterolo R, Escribano J, Langhendries JP, Dain E, Giovannini M, Verduci E, Gruszfeld D, Socha P, Koletzko B, European Childhood Obesity Trial Study Group: Lower protein content in infant formula reduces BMI and obesity risk at school age: follow-up of a randomized trial. Am J Clin Nutr 2014, 99:1041-1051.

doi:10.1186/1824-7288-40-S1-A49

Cite this article as: Verduci et al:: Protein intake and nutritional

programming: metabolic consequences. Italian Journal of Pediatrics 2014 40(Suppl 1):A49.

\section{Submit your next manuscript to BioMed Central} and take full advantage of:

- Convenient online submission

- Thorough peer review

- No space constraints or color figure charges

- Immediate publication on acceptance

- Inclusion in PubMed, CAS, Scopus and Google Scholar

- Research which is freely available for redistribution

Submit your manuscript at www.biomedcentral.com/submit
Ciomed Central 